\title{
In-vitro evaluation of the efficacy of PIPS irrigation system on disinfection of type 2 canal systems in molars
}

\begin{abstract}
Objective: This in vitro study was designed to compare the disinfection potential of an Er:YAG photon-initiated photoacousitc (PIPS) irrigation mechanism to standard needle irrigation (SNI) in eliminating biofilms from complex root canal systems.

Method and materials: Twenty-four extracted mandibular molar teeth exhibiting a Vertucci Type II canal system were selected and underwent canal instrumentation to create either a minimal (20/.04) or fully-flared (25/.06) preparation. Teeth were inoculated with bacterial plaque and incubated for 3 weeks creating a mature biofilm. Both instrumentation groups were sub-divided according to mode of canal disinfection: sterile saline or sodium hypochlorite $(\mathrm{NaOCl})$ with PIPS laser-activation or same irrigants delivered with SNI. Each irrigation protocol used similar quantities of $\mathrm{NaOCl}$ or saline over the same time periods. Viable intracanal bacteria were quantified by MTT bacterial viability assay. Sub-groups were analyzed for statistical significance by anova, followed by Scheffe's F-test $(P=.05)$.

Results: All saline groups showed significantly more viable bacteria after irrigation than the corresponding $\mathrm{NaOCl}$ sub-groups. The \#20/.04 sub-group that underwent PIPS and $\mathrm{NaOCl}$ irrigation had greater disinfection than the SNI counterpart, which was not significant $(P>0.05)$. The $\# 25 / .06 \mathrm{PIPS} / \mathrm{NaOCl}$ sub-group showed greater disinfection than SNI $(P>0.0008)$. All other groups showed no significant differences in disinfection of root canals.

Conclusion: In this in vitro study PIPS laser-activated irrigation achieved higher disinfection in \#25/.06 fully-flared preparations than SNI. Although not significantly different, greater disinfection was found in the \#20/.04 minimal canal preparations that were treated with PIPS irrigation compared to SNI.
\end{abstract}

Keywords: photon-initiated photoacousitc (PIPS) irrigation, Biofilm; type 2 canal system, mixed bacterial oral plaque, MTT assay
Volume 7 Issue 2 - 2017

\author{
Alexander Garcia Godoy,' David J Clement,' \\ Adam Lloyd, I David Tipton, ${ }^{2}$ Jegdish P Babu ${ }^{2}$ \\ 'Department of Endodontics, The University of Tennessee \\ Health Science Center, USA \\ ${ }^{2}$ Department of Bioscience Research, The University of \\ Tennessee Health Science Center, USA
}

\begin{abstract}
Correspondence: Jegdish P Babu, Department of Biosceince Research, College of Dentistry, University of Tennessee Health Science Center, 71 I Jefferson Avenue, Suite 426, Memphis Tennessee, 38163, USA, Tel 90I448-4342, Fax 901448-7860, Email Jbabu@uthsc.edu
\end{abstract}

Received: February 02, 2017 | Published: April 26, 2017

\section{Introduction}

Apical periodontitis results from cultivable bacteria found within an infected root canal system that elicits host defences. ${ }^{1}$ Elimination of the intracanal microbiome, or reduction to a subcritical level, is essential for periapical healing to occur. ${ }^{2}$ Chemomechanical preparation that removes organic tissue, infected dentin and dislodges biofilms has been shown to be clinically effective in elimination of patient symptoms with concomitant radiographic healing. ${ }^{3,4}$ Bacterial contamination related to non-healing apical lesions healing is the primary etiology of post-treatment disease requiring retreatment, periapical surgery or extraction. ${ }^{5}$ A significant challenge for instrumentation and disinfection is the inability of contemporary techniques to address all the complexities of root canal systems. ${ }^{6} \mathrm{~A}$ determinant factor for endodontic success is creating convenience form and canal shape that permits canal disinfection, specifically addressing areas of the root canal system that remain untouched by instruments. A recent change in the study of bacterial colonization of root canals has moved the focus from single organism laboratorybased planktonic cultures to the biofilm mode of growth. ${ }^{7}$ Within the confines of the root canal system, residual biofilm is common even following irrigation with $5 \%$ sodium hypochlorite. ${ }^{8}$ Furthermore, oral mixed biofilms are more resistant to removal having a greater adhesion to dentin. ${ }^{9}$ Many alternative irrigation techniques intended to replace or serve as adjuncts to standard needle irrigation have been investigated including: passive or active ultrasonics, ${ }^{10,11}$ sonic agitation, ${ }^{12}$ photo- activated dyes (PAD) $;^{13}$ negative apical pressure devices ${ }^{14}$ and most recently photon-initiated photoacoustic streaming (PIPS). ${ }^{15}$ Laser activation of intra-canal irrigant creates large elliptical vapor bubbles that expand and subsequently implode, causing a cavitation and shock wave effect that promotes debridement and smear layer removal and the release of energy further down the canal. ${ }^{16}$ Previous studies have shown PIPS to be effective in biofilm elimination, ${ }^{17}$ smear layer removal, ${ }^{16}$ and debris removal from complex nonseparated systems. ${ }^{18}$ Apical size and taper size have been studied in the past by multiple studies, with varying conclusions reflecting the needs of obturation and irrigation techniques. ${ }^{19,20}$ The combination of varying tip size and taper continues to be studied, aimed at improving canal disinfection while conserving dentin. As apical preparation size increases, irrigant replacement was enhanced, providing space existed between the needle and the canal wall. ${ }^{21}$ Increased canal taper also improved fluid interchange and reduced the risk of extrusion; minimal taper with large apical preparations also improved irrigant replacement. ${ }^{22} E x$ vivo investigation of the optimal tip size taper combination for laser activated irrigation have yet to be determined. The objective of this study was to examine the disinfection of intentionally contaminated Type II canals in the mesial root of mandibular molars by comparing needle flushing versus PIPS activation during endodontic irrigation of complex Vertucci Type II canal systems of two different sizes and taper. The null hypothesis was that no difference exists between bacterial disinfection present in \#20/.04 taper and \#25/.06 flared taper preparations using either PIPS or needle irrigation. 


\section{Methods and materials}

Tooth collection conformed to the protocols approved by the Institutional Review Board of the University of Tennessee Health Science Center with no identifiable data associated with samples obtained (IRB 10-00832-XP). Digital radiographs were used to identify mandibular molars with similar root lengths and fully-formed apices, with two distinctly separate canals from orifice to apex, with a common apical segment. ${ }^{23}$ This canal system is notable for having cul-de-sacs and communicating isthmuses. A coronal reservoir with sufficient volume of irrigant is essential to photoacoustic wave propagation by the Er: YAG laser and PIPS tip. Samples that had broken down walls that would allow irrigant to flow out of the chamber were repaired with composite (ParaCore, Coltène Whaledent, Altstätten, Switzerland) such that all chambers were of similar height and anatomical dimension. Polyalkenoate cement (GC Fuji IX, GC America, Alsip, Ill.) was used to seal the orifice of each distal canal to prevent establishing a biofilm in the distal system. Mixed bacterial plaque samples were collected from laboratory personnel and grown in Todd Hewitt Broth (BD Diagnostics, Sparks, Md.) at $37^{\circ} \mathrm{C}$ for $24 \mathrm{hrs}$ in the presence of $5 \% \mathrm{CO} 2 .{ }^{24} \mathrm{~A}$ standard bacterial suspension $(1 \times 108$ cells $/ \mathrm{ml})$ was prepared by measuring the optical density at $600 \mathrm{~nm}$ and confirmed by the plate dilution method. All teeth were kept in saline throughout the experiment and sterilized between uses by steam autoclave. Once sterilized, samples were transferred to sterile glass vials containing $15 \mathrm{ml}$ of sterile Todd Hewitt Broth (THB) and incubated at $37^{\circ} \mathrm{C}$ for 24 hours. No bacterial growth confirmed sample sterility. Each sample was repeatedly used in the different subgroups, outlined below, as sterility was achievable with the teeth serving as a control. Each sub-group was repeated twice.

\section{Canal instrumentation technique}

Twenty-four mandibular molars were divided into either a minimal canal (20/.04) or fully-flared (25/.06) preparation. Irrigation protocols further subdivided the samples into four subgroups per preparation technique, each comprised of an irrigation delivery mechanism and irrigant (Table 1). The mesial canals were negotiated to their apical terminus and a minimum pathway developed with size $10 \mathrm{~K}$-files (Roydent, Johnson City, Tenn.). Canals were enlarged to an apical matrix of $0.20 \mathrm{~mm}$ at a length $0.05 \mathrm{~mm}$ short of observing a file at the canal terminus. Crown-down preparation was completed using a complete series of rotary nickel-titanium (NiTi) instruments (ProFile Vortex, Dentsply Tulsa Dental Specialties, Tulsa, Okla.) in either .04 taper (\#40/.04 to 20/.04) or .06 taper (40/.06 to 25/.06). Additionally, Vortex Orifice Openers (Dentsply Tulsa Dental Specialties) were used to create coronal flare in the fully-flared group. Each canal had to demonstrate resistance with the last NiTi instrument in the apical third to guarantee correct group allocation.
Table I Irrigation protocol followed in disinfection of infected root canals, in vitro

\begin{tabular}{|c|c|}
\hline Saline protocol & Sodium hypochlorite protocol \\
\hline $6 \mathrm{ml}$ Saline over $30 \mathrm{sec}$ & $6 \mathrm{ml}$ Hypochlorite over $30 \mathrm{sec}$ \\
\hline Wait 30 seconds & Wait 30 seconds \\
\hline $6 \mathrm{ml}$ Saline over $30 \mathrm{sec}$ & $6 \mathrm{ml}$ Hypochlorite over $30 \mathrm{sec}$ \\
\hline Wait 30 seconds & Wait 30 seconds \\
\hline $6 \mathrm{ml}$ Saline over $30 \mathrm{sec}$ & $6 \mathrm{ml}$ Hypochlorite over $30 \mathrm{sec}$ \\
\hline Wait 30 seconds & Wait 30 seconds \\
\hline $6 \mathrm{ml}$ Saline over $30 \mathrm{sec}$ & $6 \mathrm{ml}$ Saline over 30 seconds \\
\hline $6 \mathrm{ml} 17 \%$ EDTA over $30 \mathrm{sec}$ & $6 \mathrm{ml} 17 \%$ EDTA over 30 seconds \\
\hline $6 \mathrm{ml}$ Saline over $30 \mathrm{sec}$ & $6 \mathrm{ml}$ Saline over 30 seconds \\
\hline $6 \mathrm{ml}$ Saline over $30 \mathrm{sec}$ & $6 \mathrm{ml}$ Saline over 30 seconds \\
\hline $6 \mathrm{ml}$ Saline over $30 \mathrm{sec}$ & $6 \mathrm{ml}$ Saline over 30 seconds \\
\hline
\end{tabular}

\section{Creating mature intracanal biofilms}

All prepared teeth were infected by injecting $40 \mu 1$ of the standard bacterial suspension $(1 \times 108 \mathrm{cells} / \mathrm{ml})$ equally into both mesiobuccal and mesiolingual canals. An established protocol for the creation of a 3 week biofilm was followed, with the addition of $0.5 \mathrm{ml}$ fresh THB to each sample every 2 days during the incubation cycle. ${ }^{24}$ Following incubation, but prior to irrigation, the external apical third of each mesial root was coated with sticky wax (Kerr Dental Laboratory Products, Orange, Calif.).

\section{Irrigation}

Sterile saline (Baxter International Inc., Deerfield, Ill.) or $6.0 \%$ sodium hypochlorite (diluted from $8.25 \%$ stock solution; The Clorox Company, Oakland, Calif.) were delivered using PIPS or SNI, followed by $17 \%$ EDTA (Roth International Ltd., Elgin, Ill.) as irrigating solutions. The irrigation regimen required $18 \mathrm{ml}$ of irrigant (saline or $6 \% \mathrm{NaOCl}$ ), $6 \mathrm{ml}$ of sterile saline, $6 \mathrm{ml}$ of $17 \%$ EDTA and $18 \mathrm{ml}$ of additional saline delivered over a period of 6 minutes (Table 2), a protocol documented previously. ${ }^{18}$ The $9 \mathrm{~mm}$ long, $600 \mu \mathrm{m}$ diameter PIPS tip was moved in a constant circular motion within the chamber while irrigants were delivered by syringe. The PIPS tip did not touch the chamber walls or enter the canal orifices. Energy was supplied by a $2940 \mathrm{~nm}$ wavelength Er: YAG laser (LightWalker DT, Fotona, Ljubljana, Slovenia), at $15 \mathrm{~Hz}$ and $20 \mathrm{~mJ}$ at 30 second intervals. SNI was performed using a $30 \mathrm{Ga}$. side-vented needle (ProRinse irrigation probes, Dentsply Tulsa Dental Specialties) by placing the tip as apical as possible without binding, at least $1 \mathrm{~mm}$ short of working length. Irrigants were delivered with an up and down motion within the canal system.

Table 2 Viable bacteria recovered from root canals following irrigation methods used in the study

\begin{tabular}{|c|c|c|c|c|c|}
\hline$\bullet$ & Root Canal Treatment & - Mean Bacteria \pm Se & $\bullet$ & $\bullet$ & $\bullet$ \\
\hline$\bullet$ & PIPS Saline .04 & - $\quad 193.4 \pm 19.10$ & - $\mathrm{A}$ & $\bullet$ & $\bullet$ \\
\hline - & PIPS $\mathrm{NaOCl} .04$ & - $\quad 19.43 \pm 6.13$ & $\bullet$ & - $\mathrm{B}$ & $\bullet$ \\
\hline$\bullet$ & SNI Saline .04 & - $\quad 245.2 \pm 13.75$ & - $\mathrm{A}$ & $\bullet$ & $\bullet$ \\
\hline • & SNI NaOCl .04 & - $\quad 32.7 I \pm 6.01$ & $\bullet$ & - $\mathrm{B}$ & $\bullet$ \\
\hline$\bullet$ & PIPS Saline .06 & - $\quad 251.14 \pm 18.60$ & - $\mathrm{A}$ & $\bullet$ & $\bullet$ \\
\hline$\bullet$ & PIPS $\mathrm{NaOCl} .06$ & - $\quad 10.75 \pm 4.35$ & $\bullet$ & $\bullet$ & - $\mathrm{C}$ \\
\hline$\bullet$ & Needle Saline .06 & - $\quad 279 \pm 10.99$ & - $\mathrm{A}$ & $\bullet$ & $\bullet$ \\
\hline$\bullet$ & Needle $\mathrm{NaOCI} .06$ & - $\quad 34.33 \pm 4.07$ & $\bullet$ & - $B$ & $\bullet$ \\
\hline
\end{tabular}

Columns with similar letters are not statistically significant according to anova $(\mathrm{P}>.05)$ 


\section{Quantifying intra-canal bacterial viability following irrigation}

Following the final saline rinse, a new sterile $30 \mathrm{Ga}$. needle was used to withdraw $10 \mu 1$ of fluid from the canal system into a sterile tuberculin syringes. The solution was placed in a sterile 96-well microtitre plate along with $90 \mu 1$ of sterile saline. The number of viable bacteria was determined by the MTT bacterial viability assay (Roche Diagnostics Corp., Indianapolis, Ind.). The assay is based upon the reduction of yellow tetrazolium salt (3-(4, 5-dimethylthiazolyl-2)2,5-diphenyltetrazolium bromide) by metabolically active bacterial cells by the action of dehydrogenase enzymes. The resulting purple formazan crystals formed after a 4 hour incubation period with MTT label were further incubated with the provided solubilizing solution overnight at $37^{\circ} \mathrm{C}$ and the absorbance measured at $560 \mathrm{~nm}$ using a spectrophotometer (SPECTROstar, BMG LABTECH Inc., Cary, N.C.). The number of viable bacteria were calculated from the MTT absorbance values of a standard curve prepared with a known number of bacteria. Data were analyzed for statistical significance by anova, followed by Scheffe's F-test, with $P<0.05$ considered significant.

\section{Results}

The number of viable bacteria obtained from root canals was found to be different depending upon the irrigation protocol (Table 1). The highest number of bacteria was retrieved from root canals irrigated with sterile saline. The number of viable bacteria found in the 20/.04 and 25/.06 tapered canal preparations irrigated with sterile saline by SNI were $245 \pm 13.75$ and $279 \pm 10.99$, respectively. There was no significant difference between these groups. Following sterilization and re-inoculation of the same samples, $\mathrm{NaOCl}$ by SNI resulted in a significant reduction $(87 \% ; P<0.0001)$ in viable bacteria (Table 3$)$. Greater bacterial reduction occurred in canals irrigated with saline and PIPS (193.4 \pm 19.1$)$ compared to sterile saline and SNI (245.2 \pm 13.75$)$ in.04 tapered canal preparations, but the difference was not significant $(=0.0546)$. The .06 tapered canals also showed similar results (Table 3). Irrigation with $\mathrm{NaOCl}$ exhibited no significant difference in viable bacterial counts obtained from minimal tapered or fully flared canals using SNI (Figure $1 \& 2$ ). The PIPS irrigation protocol resulted in $19.43 \pm 6.13$ viable bacteria in 20/.04 tapered canals, while the $25 / .06$ preparations showed $10.75 \pm 4.35$ bacteria. Significant differences in the number of viable bacteria were found between $\mathrm{NaOCl}$ delivered using either SNI or PIPS (Table 3). The 20/.04 minimal preparation with $\mathrm{NaOCl}$ and PIPS exhibited greater disinfection of the root canal system, but the difference in viable bacteria was not significant $(P=0.1186)$.

Table 3 Demonstration of values among root canal treatments exhibiting significant difference

\begin{tabular}{ll}
\hline Root canal treatment & PValues \\
\hline $.04 \mathrm{SNI}$ saline and $.04 \mathrm{SNI} \mathrm{NaOCl}$ & $<0.000 \mathrm{I}$ \\
$.04 \mathrm{PIPS}$ saline and $.04 \mathrm{SNI} \mathrm{NaOCl}$ & $<0.000 \mathrm{I}$ \\
$.06 \mathrm{PIPS} \mathrm{NaOCl}$ and $.06 \mathrm{SNI}$ saline & 0.0008 \\
$.04 \mathrm{PIPS} \mathrm{NaOCl}$ and $.06 \mathrm{SNI}$ saline & $<0.000 \mathrm{I}$ \\
\hline
\end{tabular}

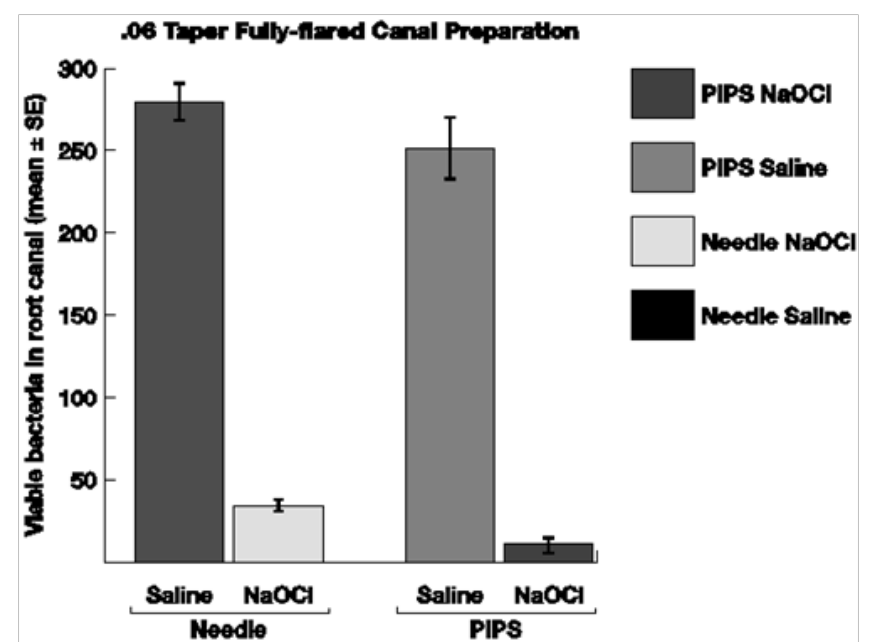

Figure I Demonstration of viable bacteria remaining in the root canals following the irrigation of a minimally shaped (\#20/.04) preparation.Values are means and standard deviations. Bars with similar letters are not statistically significant $(\mathrm{P}>0.05)$.

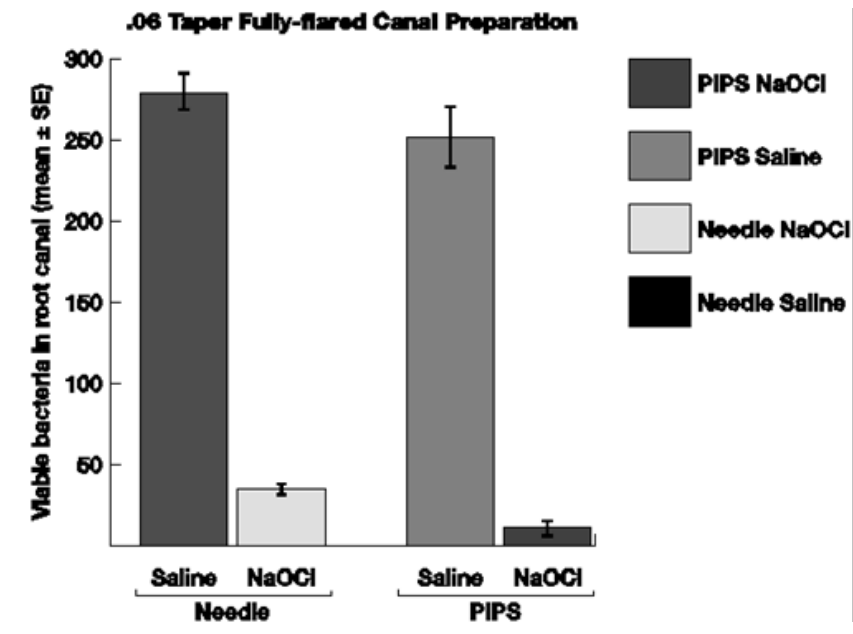

Figure 2 Demonstration of viable bacteria remaining in the root canals following the irrigation of a flared (\#25/.06) preparation.Values are means and standard deviations. Bars with similar letters are not statistically significant $(P>0.05)$. Statistical significance between $B, C(P<0.0008)$.

\section{Discussion}

This study investigated the interaction of varying canal taper with the disinfection potential of PIPS laser-activated irrigation in comparison to SNI using sterile saline or sodium hypochlorite. While no statistical differences between the tapered preparations and their disinfection potential for either irrigation method existed, a tendency for significantly greater disinfection in the fully flared .06 tapered preparations occurred when PIPS was used. This may be due to minimal shaping to an .04 taper preparation may not permit an adequate volume of active irrigant to flow to the canal terminus and cause turbulent flow sufficient to detach sessile microbes. While intracanal tissue debris has been shown to be cleared from the isthmus at 2.6 times greater than for SNI ${ }^{18}$, the isthmus remains an area from which existing organic debris, along with packed inorganic debris from instrumentation, can 
be difficult to remove. Eddy currents exist where the two canals merge into one, with a stationary area above which fluid interchange does not occur, leaving microbes present in complex nonseparated systems. This has previously been demonstrated in simulated lateral canals and isthmuses where ultrasonic activation of water or sodium hypochlorite can create stable bubbles, preventing biofilm removal in its entirety. ${ }^{25}$ Alternatively, minimal tapered preparations prevent the collection of sufficient microbes in the aliquot from the mesial root canal system. The MTT assay measures the metabolic activity of microbes and is able to provide quantification over other methods, such as turbidity or plating. A standard curve of $E$. faecalis was performed using the assay with a known number of bacteria. Similar results showing improved disinfection capability of PIPS irrigation have been reported using different analytical methodologies. ${ }^{26-28}$ The challenges of determining antibacterial efficacy are compounded by the difficulty in assessing what is actually being measured. Techniques which are commonly used, such as paper point sampling followed by CFU counting can determine general bacterial counting from the coronal third which can exclude information from the apical third, where disinfection is more indicative of irrigation efficiency and more difficult to access. Measurement of the apical third cleanliness has been attempted by direct-access methods, as well as split-model methods, both requiring structural modification of the dentin and apical complexities. ${ }^{17-31}$ While the method used in this experiment contains similar shortcomings to the paper point/CFU method with regards to sampling location, it provides expeditious sample collection, reuse of samples in order for the same sample to serve as a control, and a well-known, reliable methodology for bacterial quantification. Complex nonseparated mesial roots of mandibular molars were prepared either to a 20/.04 or 25/.06 taper, to determine the in vitro disinfection using PIPS or SNI with sodium hypochlorite. The fully flared preparation provided the highest level of intra-canal disinfection with PIPS and sodium hypochlorite. Further studies are needed regarding taper preparation requirements for optimizing disinfection, as well as evaluation of the collection of apical bacteria from intact root canal systems.

\section{Acknowledgments}

The authors like to thank the Fotona laboratory for the generous loan of the Er: YAG laser equipment for this study.

\section{Conflicts of interest}

The authors declare there is no conflict of interest.

\section{References}

1. Kakehashi S, Stanley HR, Fitzgerald RJ. The effects of surgical exposures of dental pulps in germfree and conventional laboratory rats. J South Calif State Dent Assoc. 1966;34:449-451.

2. Sundqvist G. Bacteriologic studies of necrotic dental pulps. Tryekeri: Umeå. 1976.

3. Byström A, Sundqvist G. Bacteriologic evaluation of the efficacy of mechanical root canal instrumentation in endodontic therapy. Scand $J$ Dent Res. 1981;89(4):321-328.

4. Molander A, Reit C, Dahlén G, et al. Microbiological status of root-filled teeth with apical periodontitis. Int Endod J. 1998;31(1):1-7.

5. Sundqvist G, Figdor D, Persson S, et al. Microbiologic analysis of teeth with failed endodontic treatment and the outcome of conservative re-treatment. Oral Surg Oral Med Oral Pathol Oral Radiol Endod. 1998;85(1):86-93.
6. Hess WR, Zürcher E, Dolamore WH. The anatomy of the root-canals of the teeth of the permanent dentition. England, UK: Sons and Danielson Ltd.;1952:1-199.

7. Whiteley M, Bangera MG, Bumgarner RE, et al. Gene expression in Pseudomonas aeruginosa biofilms. Nature. 2001;413(6858):860-864.

8. Vera J, Siqueira JF, Ricucci D, et al. One- versus Two-visit Endodontic Treatment of Teeth with Apical Periodontitis: A Histobacteriologic Study. J Endod. 2010;38(8):1040-1052.

9. Stojicic S, Shen Y, Qian W, et al. Antibacterial and smear layer removal ability of a novel irrigant, QMiX. Int Endod J. 2010;45(4):363-371.

10. Gutarts R, Nusstein J, Reader A, et al. In vivo debridement efficacy of ultrasonic irrigation following hand-rotary instrumentation in human mandibular molars. J Endod. 2005;31(3):166-170.

11. Roy RA, Ahmad M, Crum LA. Physical mechanisms governing the hydrodynamic response of an oscillating ultrasonic file. Int Endod J. 1994;27(4):197-207.

12. De Gregorio C, Estevez R, Cisneros R, et al. Effect of EDTA, Sonic, and Ultrasonic Activation on the Penetration of Sodium Hypochlorite into Simulated Lateral Canals: An In Vitro Study. J Endod. 2009;35(6):891895.

13. George S, Kishen A. Photophysical, photochemical, and photobiological characterization of methylene blue formulations for light-activated root canal disinfection. J Biomed Opt. 2007;12(3):034029.

14. Desai P, Himel V. Comparative Safety of Various Intracanal Irrigation Systems. J Endod. 2009;35(4):545-549.

15. Peters OA, Bardsley S, Fong J, et al. Disinfection of Root Canals with Photon-initiated Photoacoustic Streaming. J Endod. 2011;37(7):10081012.

16. Di Vito E, Peters OA, Olivi G. Effectiveness of the erbium:YAG laser and new design radial and stripped tips in removing the smear layer after root canal instrumentation. Lasers Med Sci. 2012;27(2):273-280.

17. Ordinola-Zapata R, Bramante CM, Aprecio RM, et al. Biofilm removal by $6 \%$ sodium hypochlorite activated by different irrigation techniques. Int Endod J. 2014;47(7):659-666.

18. Lloyd A, Uhles JP, Clement DJ, et al. Elimination of Intracanal Tissue and Debris through a Novel Laser-activated System Assessed Using High-resolution Micro-computed Tomography: A Pilot Study. J Endod. 2014;40(4):584-587.

19. Coldero LG, McHugh S, MacKenzie D, et al. Reduction in intracanal bacteria during root canal preparation with and without apical enlargement. Int Endod J. 2002;35(5):437-446.

20. Mickel AK, Chogle S, Liddle J, et al. The role of apical size determination and enlargement in the reduction of intracanal bacteria. $J$ Endod. 2007;33(1):21-23.

21. Boutsioukis C, Gogos C, Verhaagen B, et al. The effect of apical preparation size on irrigant flow in root canals evaluated using an unsteady Computational Fluid Dynamics model. Int Endod J. 2010;43(10):874 881 .

22. Boutsioukis C, Gogos C, Verhaagen B, et al. The effect of root canal taper on the irrigant flow: evaluation using an unsteady Computational Fluid Dynamics model. Int Endod J. 2010;43(10):909-916.

23. Vertucci FJ. Root canal anatomy of the human permanent teeth. Oral Surg Oral Med Oral Pathol. 1984;58(5):589-599.

24. Lin J, Shen Y, Haapasalo M. A Comparative Study of Biofilm Removal with Hand, Rotary Nickel-Titanium, and Self-Adjusting File Instrumentation Using a Novel In Vitro Biofilm Model. J Endod. 2013;39(5):658-663. 
25. Macedo RG, Robinson JP, Verhaagen B, et al. A novel methodology providing insights into removal of biofilm-mimicking hydrogel from lateral morphological features of the root canal during irrigation procedures. Int Endod J. 2014;47(11):1040-1051.

26. Olivi G, DiVito E, Peters O, et al. Disinfection efficacy of photon-induced photoacoustic streaming on root canals infected with Enterococcus faecalis. J Am Dent Assoc. 2014;145(18):843-848.

27. Duckhouse H, Mason TJ, Phull SS, et al. The effect of sonication on microbial disinfection using hypochlorite. Ultrason Sonochem. 2004;11(3-4):173-176.

28. Al Shahrani M, DiVito E, Hughes CV, et al. Enhanced Removal of Enterococcus faecalis Biofilms in the Root Canal Using Sodium Hypochlorite Plus Photon-Induced Photoacoustic Streaming: An In Vitro Study. Photomed Laser Surg. 2014;32(5):260-266.
29. Ma JZ, Wang ZJ, Shen Y, et al. A new noninvasive model to study the effectiveness of dentin disinfection by using confocal laser scanning microscopy. J Endod. 2011;37(10):1380-1385.

30. De Moor RJ, Meire M, Goharkhay K, et al. Efficacy of ultrasonic versus laser-activated irrigation to remove artificially placed dentin debris plugs. J Endod. 2010;36(9):1580-1583.

31. Arslan H, Capar ID, Saygili G, et al. Effect of photon-initiated photoacoustic streaming on removal of apically placed dentinal debris. Int Endod J. 2014;47(11):1072-1077. 